\title{
Report on reptile mortality due to vehicular traffic on Indo-Myanmar border at Champhai district of Mizoram, North East India
}

\author{
Daya Nand Harit $凶$
}

Received: 21.02 .2018

Revised: 28.05.2018

Accepted: 14.06.2018

\begin{abstract}
Reptiles are beautiful creatures of nature, which includes Crocodiles \& Alligators, Turtles \& tortoises, Lizards \& Snakes. They have their own ecological significance and render their very valuable silent services to mankind in various ways. Reptiles are cold blooded animals and frequently come out for basking under sun and remain in open area. These are slow moving animals. During basking and while crossing the roads, these animals are killed by vehicular traffic on roads and lose their lives. This paper highlights the preliminary report of reptilian mortality due to vehicular traffic on roads, with special reference to Champhai-Zokhawthar road on Indo Myanmar border at Champhai district of Mizoram, North East India.
\end{abstract}

Key words: - Reptile mortality, Vehicular traffic, Indo Myanmar border, Mizoram, India.

\section{Introduction}

Mizoram is one of the North Eastern Hill states of India, lies between $21^{\circ} 58^{\prime}-24^{\circ} 30^{\prime} \mathrm{N}$ latitude and $92^{0} 16^{\prime}-93^{0} 25^{\prime} \mathrm{E}$ longitude, with an area of 21081 sq. $\mathrm{km}$ having rich biodiversity, with several endemic and endangered species. It receives average rainfall around, $2500 \mathrm{~mm}$ per year. Winter and summer temperature of the area ranges from $11^{\circ} \mathrm{C}$ to $21^{\circ} \mathrm{C}$ and $20^{\circ} \mathrm{C}$ to $30^{\circ} \mathrm{C}$ respectively. Champhai is one of the districts of Mizoram state, bordering along Indo-Myanmar border of North East India. The area is rich in biodiversity due to its location in a biodiversity hot spot of the world / India, but has not been explored in details. Fauna of Mizoram (2007) is a document of Zoological Survey of India, which is mainly based on the state faunal surveys in the state. Studies on reptiles have been carried out in Mizoram (Harit \& Ramanujam, 2002, Harit, 2008, 2009, 2010; Lalthanpuia et al., 2008; Lalrinchhana and Solanki, 2015; Mathew, 2007a, 2007b) on various aspects. Hunting of reptiles (lizards) has also been reported (Lalrinchhana and Solanki, 2015). These creatures are not only hunted down for various human uses but also lose their lives during basking on roads and

Author's Address

Department of Zoology, Government Champhai College, Mizoram, 796 321, India.

E-mail.: kingkrait@gmail.com

roadsides or while crossing roads due to anthropogenic pressure.

These are cold blooded animals and normally come out for basking under sun on roads and roadsides to maintain their body temperature, where these creatures are over run by moving vehicles on roads. Behaviour and activity of reptiles is slow and sluggish due to low body temperature (Bhaskar, 2008). Reptiles being slow moving animals are also killed during day and night, while crossing roads in forested areas of unprotected forest areas. It has also been observed that vehicle drivers show less concerns towards reptiles on road then other mammals confronted on roads (Kannan, 2007). Reptiles use open areas for basking and feeding, hence vehicular traffic impacts mortality of reptiles on roads (Gokula, 1997). Reptile mortality reduces genetic diversity, diminishes the reproductive potential and lowers overall population size (Ghadage, 2013) and disturbs the existing ecosystem. There are several reports on reptilian mortality due to vehicular traffic in many areas (Das et al., 2007; Deepak and Ridhika, 2009; Ghadage, 2013; Gokula, 1997; Kannan, 2007; Vijayakumar et al., 2001). There have been no studies on reptilian mortality on roads in the state, attempt has therefore been made to study, highlight and document the reptilian mortality on roads with 
special reference to Champhai - Zokhawthar road due to vehicular traffic on Indo Myanmar border at Champhai district of Mizoram, North East India.

Study area: The observations were conducted on Champhai - Zokhawthar road on Indo Myanmar border in Champhai district of Mizoram. The total length of the road is around $23 \mathrm{~km}$. Champhai district has an area of about $3185 \mathrm{sq} \mathrm{km}$ located between $23^{\circ}$ to $24^{0} 05^{\prime} \mathrm{N}$ latitude and $93^{\circ}$ to $93^{\circ} 26^{\prime} \mathrm{E}$ longitude, situated in east of Mizoram state, bordering with Myanmar. A significant river called 'Tiau' flows on the border of India and Myanmar. The altitude of Champhai district varies from 500 to $2200 \mathrm{~m}$ above msl. The Champhai - Zokhawthar road, towards south-east, ends at Indo Myanmar border, with in Indian Territory (Fig. 1).The road from Champhai to Zokhawthar is zigzag where vehicle is driven at the speed of $20 \mathrm{~km} / \mathrm{hr}$ normally. The road passes via New Champhai, Mualkawi and Melbuk village. New Champhai road on either side is surrounded by paddy fields having sufficient low land water logged areas (Fig. 2), and then road leads to Mualkawi village and passing through Melbuk, it ends at Zokhawthar village on Indo Myanmar border. From Mualkawi to Zokhawthar the road on either side is surrounded by unprotected forests area. The road faces heavy traffic from Champhai to Zokhawthar by Trucks, Tata Sumo and other several private vehicles for diverse purposes.

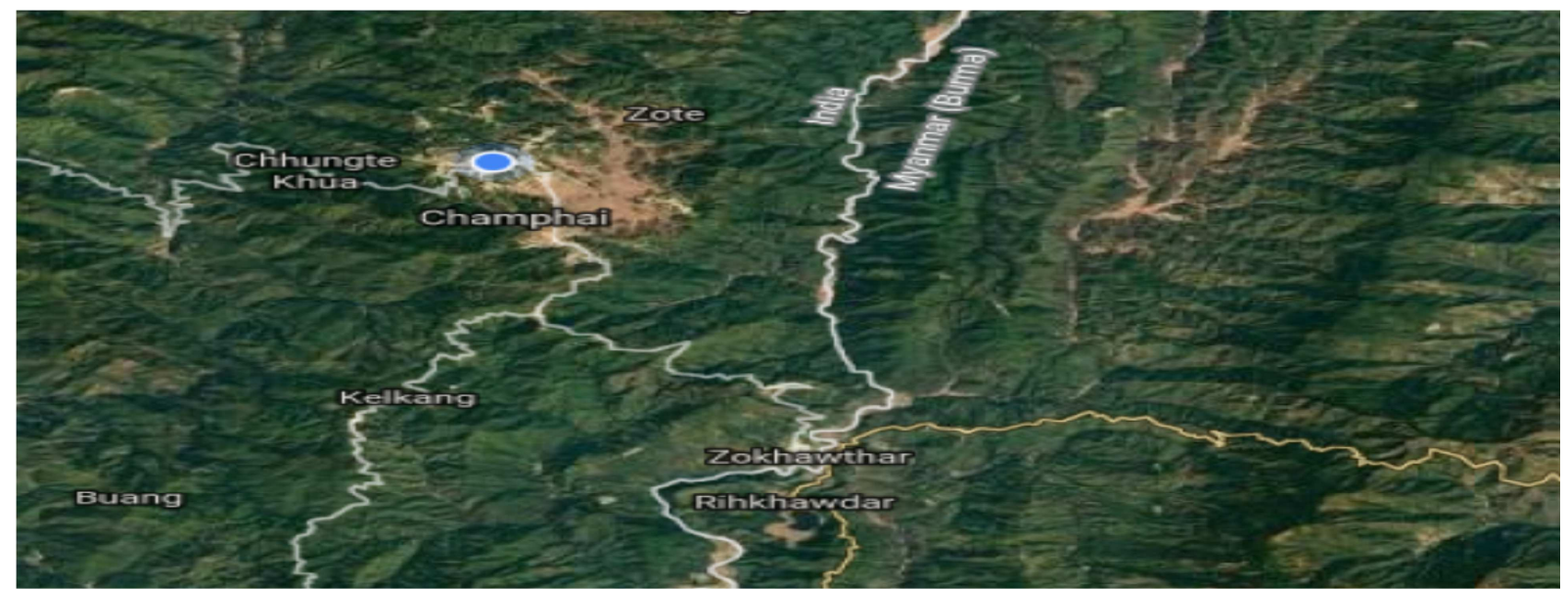

Fig. 1. Champhai - Zokhawthar Road, bordering Myanmar, Champhai district, Mizoram. (www.google.co.in/maps)

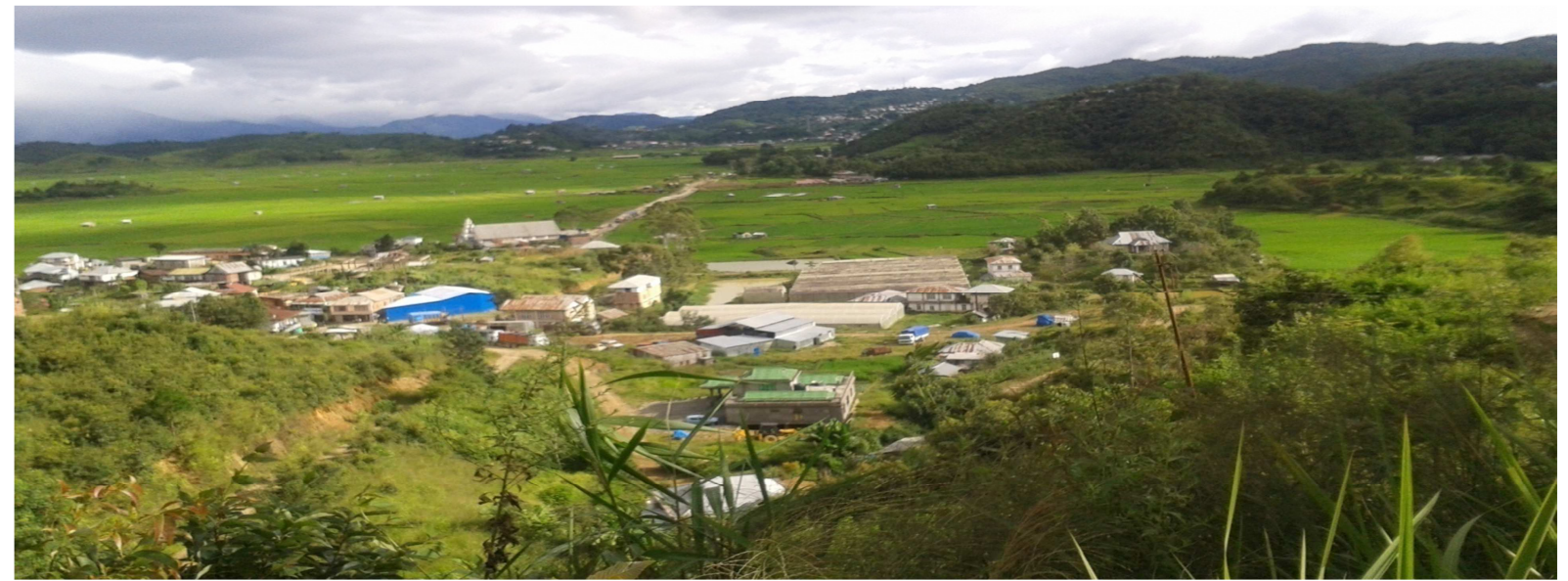

Fig. 2. Road from New Champhai leading to Zokhawthar, Indo-Myanmar Border of Mizoram. Material and Methods 
The study was conducted during 2015. Total six identification, were not taken into consideration for surveys were conducted during mid of February, data interpretation and were discarded.

March, April, July, August and September of 2015.

Surveys were conducted with slow moving vehicle from $08.00 \mathrm{am}$ to $6.00 \mathrm{pm}$ during the period mentioned. The accidental reptiles on road were observed on spot and identified with the help of literature available (Das, 2008; Mathew. 2007b; Sharma, 2002, 2003; Smith, 2003; Wall, 2000; Whitaker and Captain, 2008). Some reptiles were over crushed by vehicular traffic and were beyond

\section{Results and Discussion}

A total of 68 individuals of 17 species, belonging to five families of reptiles have been observed on roads as killed by vehicular traffic. Family Agamidae includes Calotes versicolor, Calotes jerdoni and Ptyctolaemus gularis; family Scincidae includes Sphenomorphus indicus and Sphenomorphus maculatus; family Colubridae

Table -1. Details of observed killed reptiles on roads

\begin{tabular}{|c|c|c|c|c|c|c|c|c|c|}
\hline $\mathbf{S N}$ & Family & Species & Feb. & March & April & July & August & September & Total \\
\hline 1 & \multirow{3}{*}{$\begin{array}{l}\text { Agamida } \\
\mathrm{e}\end{array}$} & Calotes versicolor & 5 & 4 & 6 & 8 & 7 & 8 & 38 \\
\hline 2 & & Calotes jerdoni & & 1 & & 1 & & & 2 \\
\hline 3 & & Ptyctolaemus gularis & & & 1 & & & 1 & 2 \\
\hline 4 & \multirow{2}{*}{ Scincidae } & $\begin{array}{l}\text { Sphenomorphus } \\
\text { indicus }\end{array}$ & & & 1 & & 1 & & 2 \\
\hline 5 & & $\begin{array}{l}\text { Sphenomorphus } \\
\text { maculatus }\end{array}$ & & 1 & & & & & 1 \\
\hline 6 & \multirow{9}{*}{$\begin{array}{l}\text { Colubrid } \\
\text { ae }\end{array}$} & $\begin{array}{l}\text { Coelognathus } \\
\text { radiatus }\end{array}$ & & 1 & 1 & & & 1 & 3 \\
\hline 7 & & $\begin{array}{l}\text { Rhadinophis } \\
\text { prasinum }\end{array}$ & & & 1 & & & & 1 \\
\hline 8 & & Sibynophis collaris & & & & & 1 & & 1 \\
\hline 9 & & $\begin{array}{l}\text { Rhabdophis } \\
\text { subminiatus }\end{array}$ & & 1 & & 2 & & 1 & 4 \\
\hline 10 & & Ahaetulla nasuta & & & 1 & & & & 1 \\
\hline 11 & & $\begin{array}{l}\text { Xenochrophis } \\
\text { piscator }\end{array}$ & & & & 1 & & & 1 \\
\hline 12 & & Oligodon albocinctus & & & & & 2 & & 2 \\
\hline 13 & & Dendrelaphis pictus & & & & & 1 & & 1 \\
\hline 14 & & Amphiesma stolatum & & & & 1 & & & 1 \\
\hline 15 & \multirow{2}{*}{$\begin{array}{l}\text { Crotalida } \\
\text { e }\end{array}$} & Ovophis monticola & & 1 & & 2 & & & 3 \\
\hline 16 & & $\begin{array}{l}\text { Trimeresurus } \\
\text { erythrurus }\end{array}$ & & 1 & & 1 & 1 & 1 & 4 \\
\hline 17 & Elapidae & Bungarus niger & & & 1 & & & & 1 \\
\hline $\begin{array}{l}\text { Tot } \\
\text { al }\end{array}$ & 05 & 17 & 5 & 10 & 12 & 16 & 13 & 12 & 68 \\
\hline
\end{tabular}




\section{Daya Nand Harit}

Table 2. Family breakup of Reptiles observed.

\begin{tabular}{|l|l|l|l|}
\hline SN & Family & Species & Percentage \\
\hline 1. & Agamidae & 3 & 17.64 \\
\hline 2. & Scincidae & 2 & 11.76 \\
\hline 3. & Colubridae & 9 & 52.94 \\
\hline 4. & Crotalidae & 2 & 11.76 \\
\hline 5. & Elapidae & 1 & 5.88 \\
\hline
\end{tabular}

includes Coelognathus radiatus, Rhadinophis prasinum, Sibynophis collaris, Rhabdophis subminiatus, Ahaetulla nasuta, Xenochrophis piscator, Oligodon albocinctus, Dendrelaphis pictus and Amphiesma stolatum; family Crotalidae includes Ovophis monticola and Trimeresurus erythrurus; family Elapidae includes only one species Bungarus niger (Table- 1 \& 2, Fig. 4). Reptiles constitute one of the important ecological links in an ecosystem and render their valuable silent services to the system. The observations were conducted on Champhai - Zokhawthar road, on indo Myanmar border, Champhai district, Mizoram, North East India. The present study shows that all the species have been reported before. The study reports a total of 17 species of reptiles as road kills. Some of the road kills were over crushed by moving vehicles and were beyond identification and have not been included in present studies. There may however be many more mortality on reptiles on other heavy traffic areas of the state. All the species reported are available locally with wide range of distribution in the area.

Individually, Calotes versicolor has highest mortality rate on roads, with total of 38 individuals observed. The species is frequently available and very common in the area. Total five families have been observed on roads as road killed. Family Agamidae includes 3 species, family Scincidae includes 2 species, family Colubridae includes 9 species, family Crotalidae includes 2 species and family Elapidae includes one species, constituting $17.67 \%, 11.76 \%, 52.94 \%, 11.79 \%$ and $5.8 \%$ respectively (Fig. 3). The road kills affect adversely the richness and population density of the species and also reduces the reproduction potential of the species (Ghatage, 2013). The place is hilly, with no straight roads, moving vehicles normally move with slow speed. Yet, the person driving the vehicle / driver show less concerns towards reptiles (Kannan, 2007) and even knowingly or unknowingly crush these animals with no sympathy. The present condition is that people are less aware of the consequences of the reduction in population richness of these creatures, conservation needs and conservation values and their valuable services rendered to ecosystem and human beings. The accident to reptiles with slow moving vehicles, being hilly area, can easily be minimized or avoided, if people are made aware of the significance of reptiles in nature and their valuable services to ecosystem and mankind. Mizoram is a small state in India, having several social and religious organisations, working for social and religious causes. A brief awareness programme on conservation issues on reptiles by non government and government bodies to vehicle drivers would render a significant service these creatures.

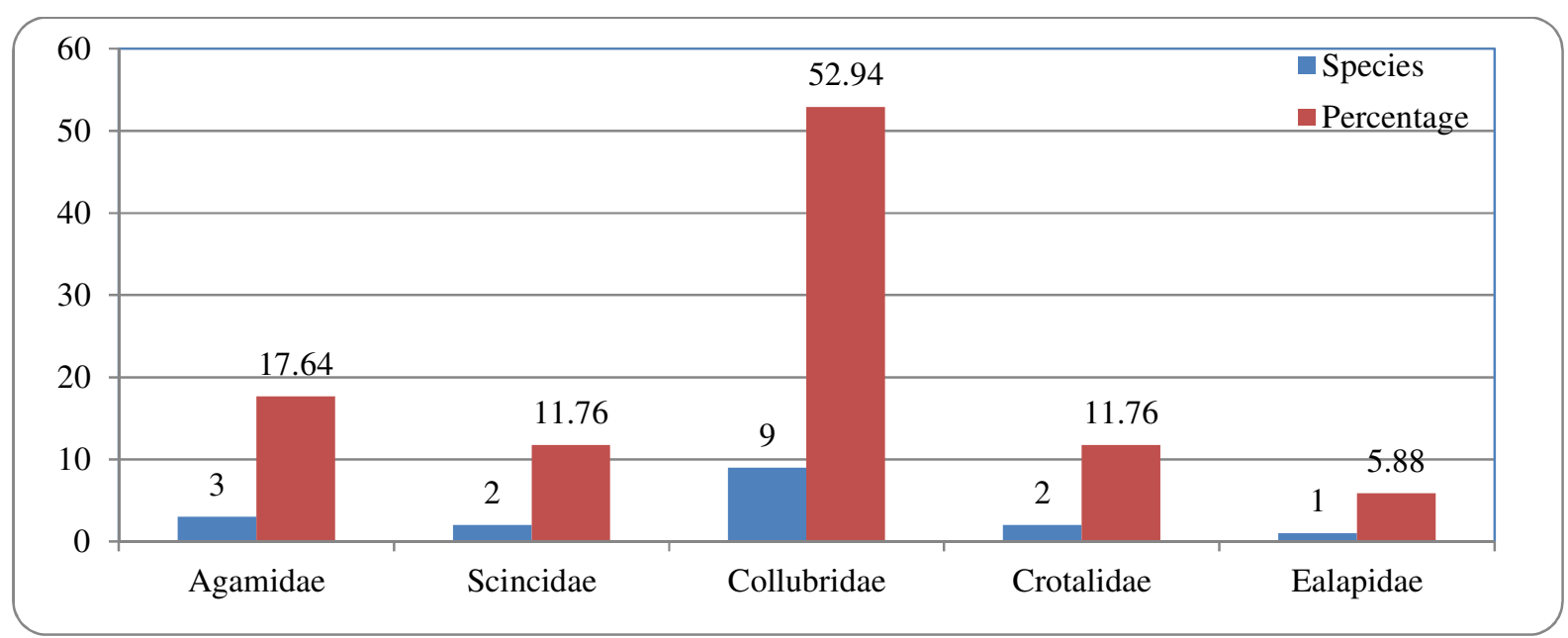

Fig - 3. Beak up of different families of Reptiles 
Report on reptile mortality due to vehicular traffic

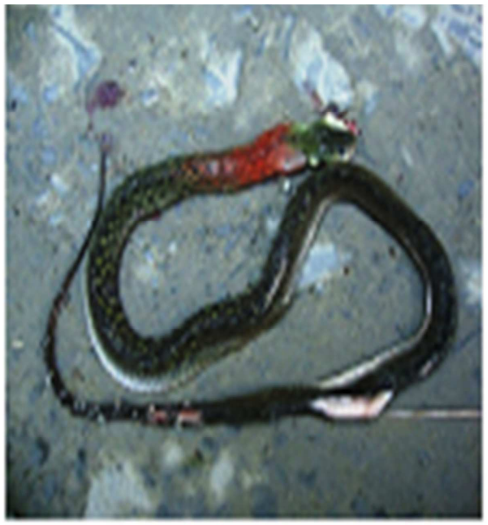

Rhabdophis subminiates

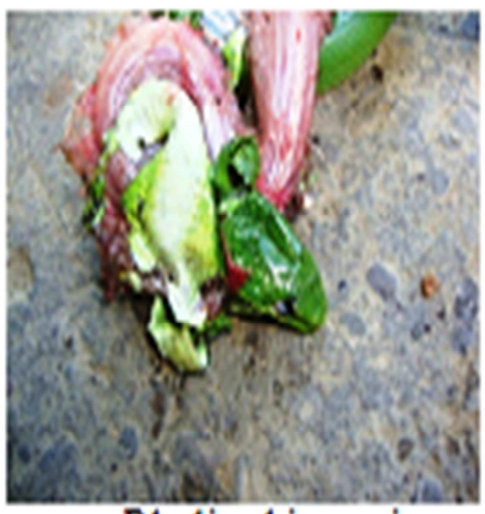

Rhadinophis prasimm

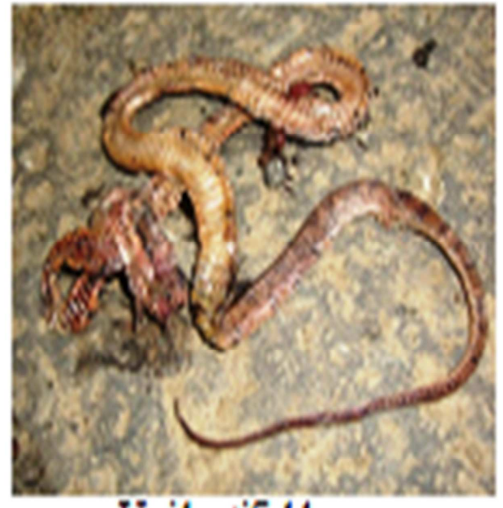

Unidentifiable

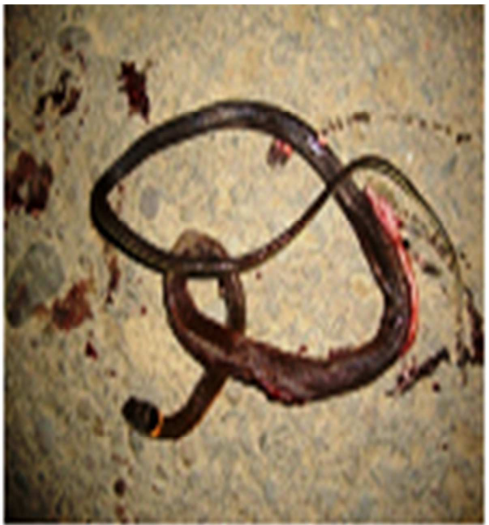

Sibynophis collanis

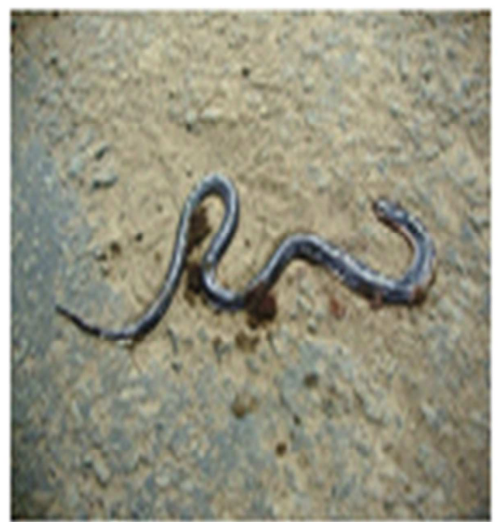

Bungarus niger

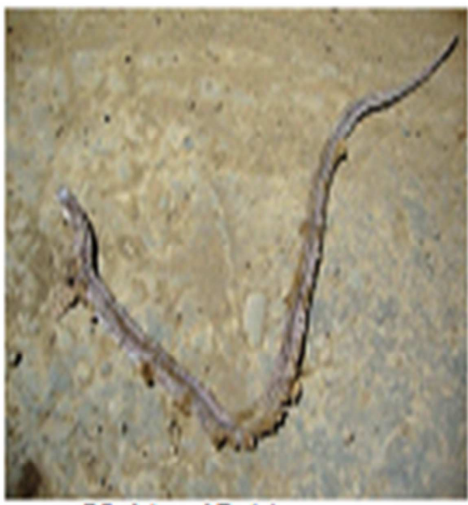

Unidentifiable

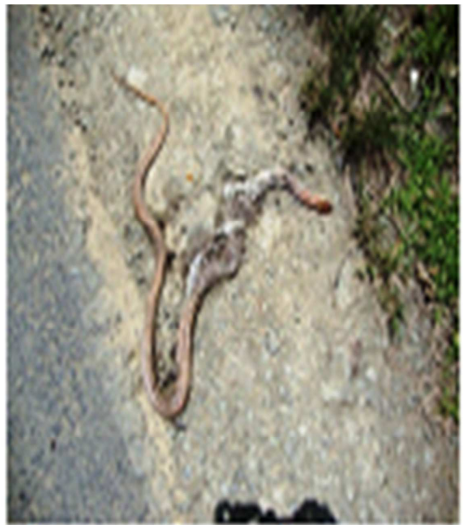

Coelognathus radiatus

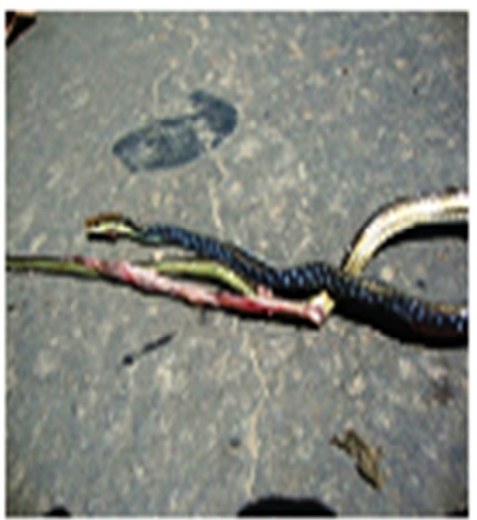

Dendrelaphis pictus

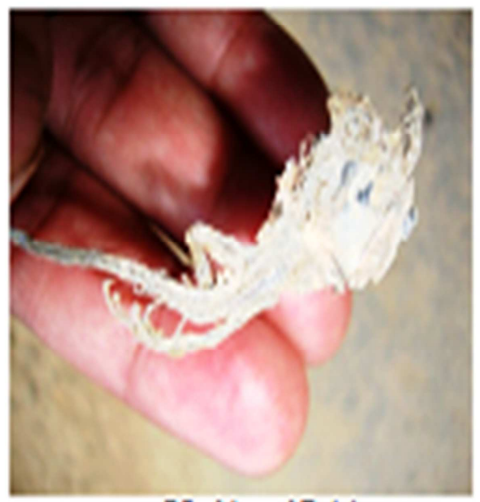

Unidentifiable

Fig. 4. Some of the reptles raad $\mathrm{k}$ illed. 


\section{Daya Nand Harit}

\section{Acknowledgements}

Author is grateful to the Principal, Government Champhai College, Mizoram, for providing facilities and University Grants Commission for funding the then Research project on Reptile studies in Mizoram, North East India.

\section{References}

Bhaskar, H.V., 2008. Animal Behaviour. Campus Books International, Delhi. P-324. ISBN : 81-8030-109-5.

Das, I., Ahmed, A.F., Lakhar, B.P. and Sharma P., 2007. A preliminary report of reptilian mortality on roads due to vehicular movement near Kaziranga National Park, Assam, India. Zoo's Print Journal 22(7) : 2742-2744.

Das I. (2008). A pictographic Guide to Snakes and other reptiles of India. Om Books International, New Delhi. ISBN : 81-87108-35-5.

Deepak, R. and Ridhika, V.K., 2009. A report on reptile road kills in a rural area of Tamil Nadu, India. Cobra 3(4) : 914.

Ghatage, M.K., 2013. Road kills of reptiles in the region of Khed Tahsil, Pune, MS, North western Ghats, India. International Research Journal of Animal Veterinary and Fishery Sciences 1(4) : 15-17.

Gokula, V., 1997. Impact of vehicular traffic on snakes in Mudumalai wildlife sanctuary. Cobra $27: 26$.

Harit, D.N. and Ramanujam, S.N., 2002. Reptilian fauna of Mizoram, India. Cobra 47: 5-7.

Harit, D.N., 2008. Poisonous snakes in Mizoram, North East India. Indian Journal of Environment and Ecoplanning $15(1-2): 379-383$.

Harit, D.N., 2009. Chelonians and Lizards in Champhai district of Mizoram state, North East India. Journal of Experimental Zoology, India 12(2) : 289-296.
Harit, D.N., 2010. Non poisonous snakes (Reptilia : Ophidia) of Champhai district of Mizoram state, North East India. Journal of Environment and Biosciences 24(1) : 65-75.

Kannan, P., 2007. Mortality of Reptiles due to vehicular traffic in Mudumalai wildlife sanctuary, Western Ghats, Tamil Nadu, India. Cobra 1(3) : 1-3.

Lalthanpuia, T.C., 2008. Snakes (Reptilia : Serpents) of Mizoram University Campus, Tanhril, Aizawl, with a note on their identification keys (in Mizo). Science Vision 8(4) : 112-127.

Lalrinchhana, C. and Solanki, G. S., 2015. Lizards (Reptilia : Sauria) diversity of Dampa Tiger Reserve, Mizoram, India. Science Vision 15(1) : 19-28.

Mathew, R., 2007a. Additions to the snake fauna of Mizoram. Cobra 1(1) : 5-9.

Mathew, R., 2007b. Reptilia. In : Fauna of Mizoram, state faunal series 14, Zoological Survey of India, Kolkata. p. 545-577. ISBN : 978-81-8171-163-2.

Sharma, R.C., 2002. Fauna of India and the adjacent countries : Reptilia Vol. II (Sauria). Zoological Survey of India, Kolkata. ISBN : 81-85874-70-0.

Sharma R.C., 2003. Hand Book of Indian Snakes. Zoological Survey of India, Kolkata. ISBN : 81-8171-16-9.

Smith M.A., 2003. Hand Book of Indian Snakes. Cosmo Publications, New Delhi. ISBN : 81-7755-743-2.

Vijaykumar, S.P., Vasudevan, K. and Ishwar N.M., 2001. Herpetofaunal mortality on roads in Annamalai Hills, southern western ghats. Hamadryad 26(2) : 253-260.

Wall F., 2000. The Poisonous Terrestrial Snakes. Asiatic Publishing House. ISBN : 81-87067-35-7.

Whitaker R and Captain Ashok, 2008. Snakes of India the field Guide. Draco Books Chennai, India. ISBN : 81901873-2-5. 